\title{
Penanaman etika komunikasi digital di pesantren melalui pemanfaatan e-learning
}

\author{
Rila Setyaningsih ${ }^{1}$, Abdullah $^{2}$, Edy Prihantoro $^{3}$, Hustinawaty ${ }^{4}$ \\ ${ }^{1,2}$ Universitas Darussalam Gontor, Ponorogo, Indonesia \\ ${ }^{3,4}$ Universitas Gunadarma, Depok, Indonesia
}

\begin{abstract}
ABSTRAK
Pemanfaatan e-learning dalam pembelajaran juga menjadi sebuah inovasi dalam menyongsong era society 5.0. Relasi mahasiswa santri UNIDA Gontor dengan dunia luar dibatasi dengan berbagai regulasi yang ada, termasuk juga dalam pemanfaatan media digital. Etika komunikasi digital menjadi hal penting yang harus dimiliki mahasiswa santri dalam setiap interaksi melalui media digital. Tujuan penelitian ini untuk mengetahui strategi penanaman etika komunikasi digital di pesantren dalam menyongsong era society 5.0 melalui pemanfaatan e-learning. Penelitian ini berupa kualitatif deskriptif. Pengumpulan data melalui wawancara dan observasi dengan pengelola program studi dan dosen-dosen pengampu mata kuliah dasar Ilmu Komunikasi Universitas Darussalam Gontor yang merupakan lembaga pendidikan tinggi berbasis pesantren. Teknik analisis data dilakukan berdasarkan teori Milles dan Huberman. Keabsahan data penelitian dilakukan dengan triangulasi sumber dan metode. Hasil penelitian menunjukkan bahwa strategi penanaman etika komunikasi digital di Universitas Darussalam Gontor dengan memanfaatkan e-learning dilakukan berdasarkan standar literasi media islam daring. Terdapat tujuh standar literasi media islam daring yang dijadikan rujukan dalam menanamkan etika komunikasi digital kepada para mahasiswa santri meskipun pelaksanaannya belum secara maksimal. Ketujuh standar tersebut terdiri dari prinsip produksi konten, etika distribusi informasi, jaminan akurasi dan komitmen anti hoak, semangat amar ma'ruf nahi munkar, asas hikmah dalam dakwah, prinsip interaksi digital, dan prinsip kebebasan. Pembelajaran e-learning mata kuliah dasar ilmu komunikasi menjadi sarana dalam menanamkan etika komunikasi digital menyongsong era society 5.0. Kontribusi penelitian ini berupa strategi penanaman etika komunikasi digital melalui pemanfaatan e-learning menyongsong era society 5.0 di lembaga pendidikan tinggi berbasis pesantren.
\end{abstract}

Kata-kata Kunci: Etika; komunikasi digital; pesantren; standar literasi; e-learning

\section{Digital communication ethics cultivation in pesantren through e-learning utilization}

\section{ABSTRACT}

The use of e-learning in has become an innovation in welcoming the era of society 5.0. The relationship between santri of UNIDA Gontor and the outside world is limited by various regulations, including the use of digital media. The ethics of digital communication becomes an important thing that must be owned by students of santri in every interaction through digital media. The purpose of this study was to determine the strategy of planting digital communication ethics in pesantren in welcoming the era of society 5.0 through the use of e-learning. This type of research is qualitative. Data collection was carried out through observation and interviews with study program managers and lecturers supporting the basic course of Communication Studies at University of Darussalam Gontor as a boarding university. Data analysis technique conducted by reduction, data presentation, and conclusions. The validity of the research is conducted by triangulation of sources and methods. The results of this study indicate that the strategy of digital communication ethics cultivation through the use of e-learning at UNIDA Gontor is based on online media literacy standards although the implementation has not been maximized. The seven standards consist of content production principles, information distribution ethics, guarantee of accuracy and commitment anti-hoak, spirit amar ma'ruf nahi munkar, wisdom in da'wah principles, digital interaction principles, and freedom principles. The contribution of this research is in the form of a strategy of digital communication ethics cultivation through the use of e-learning to welcome the era of society 5.0 in boarding university.

Keywords: Ethics; digital communication; boarding university; literacy standards; e-learning

Korespondensi: Rila Setyaningsih, M.S.I., Universitas Darussalam Gontor, Jl. Raya Siman, Km. 06 Siman, Ponorogo,63471.Email: rilasetya@unida.gontor.ac.id 


\section{PENDAHULUAN}

Berkembangnya teknologi digital menuntut manusia untuk terus berpikir logis dan cakap dalam menyesuaikan diri dengan perkembangan zaman. Aktifitas manusia dalam berbagai aspek kehidupan telah dimudahkan dengan hadirnya teknologi digital. Penyesuaian diri terhadap munculnya teknologi digital menjadi suatu keharusan terutama dalam menyongsong era society 5.0. Berhasil tidaknya penyesuaian diri setiap individu terhadap perkembangan zaman sangat bergantung pada kemampuan adaptasi dan inovasi. Manusia juga dituntut untuk melakukan inovasi secara berkelanjutan agar tidak mengalami ketertinggalan.

Keberadaan teknologi digital tanpa disadari telah menghapus batas-batas geografi dan waktu. Teknologi digital juga memudahkan manusia dalam mencari informasi secara real time. Di sisi lain, teknologi informasi secara lebih jauh telah mampu mempengaruhi sistem sosial, tatanan hidup dan bahkan mengganti sistem yang sudah ada. Sistem yang sudah mapan dapat saja bergeser dengan muncul dan berkembangnya teknologi digital.

Konsep "Society 5.0" mendorong manusia untuk memainkan peran yang lebih besar dalam memanfaatkan teknologi digital sehingga terbuka peluang dalam mencapai kehidupan yang bermakna. Pemanfaatan teknologi digital menyongsong era society 5.0 diarahkan dalam menciptakan inovasi sehingga memunculkan berbagai peluang untuk meraih kehidupan lebih baik. Hal ini tentunya dengan tujuan untuk menciptakan sebuah wisdom dan peradaban yang lebih maju.

Hadirnya era digital membawa banyak perubahan dalam gaya hidup masyarakat. Era digital telah mengubah hidup dan kerja manusia yang sebenarnya berkaitan dengan perubahan konsep dalam dunia teknologi. Era digital menuntut manusia untuk terus berpikir logis dan cakap dalam menyesuaikan diri dengan perkembangan informasi yang dikemas melalui media digital. Era digital juga menuntut manusia untuk terus bersaing dalam melakukan inovasi berbasis teknologi. Keberadaan teknologi informasi tanpa disadari telah menghapus batas-batas geografi dan waktu, secara lebih jauh telah mampu mempengaruhi sistem sosial, tatanan hidup dan bahkan mengganti sistem yang sudah ada.
Fenomena gaya hidup digital sudah menjadi cara dan bagian hidup banyak orang di dunia. Ciri utama perkembangan teknologi digital adalah kepraktisan. Fenomena gaya hidup digital ternyata ikut mengubah cara dalam berkomunikasi. Komunikasi merupakan bagian penting dalam kehidupan yang bertujuan membentuk jaringan antar individu dan antar kelompok sosial. Permasalahan yang sering muncul di era digital adalah tatanan komunikasi sosial yang seringkali dirusak oleh penyebaran hoax, hate speech, provokasi, dan sebagainya. Proses komunikasi yang seperti itu tidak lagi menghasilkan makna dan pengertian, namun justru memancing emosi, amarah, dan kebencian. Etika komunikasi penting untuk diinternalisasi dan diimplementasikan dalam dunia pendidikan.

Dunia pendidikan harus mulai mempersiapkan diri dalam menyongsong era society 5.0. Penyesuaian diri lembaga pendidikan tinggi menjadi suatu keharusan, karena jika tidak maka instansi tersebut akan tertinggal. Langkah penyesuaian diri juga harus dilakukan oleh lembaga perndidikan tinggi berbasis pesantren. Hal ini karena lembaga pendidikan tinggi pesantren (boarding university) menjadi bagian dari sistem pendidikan di Indonesia. Mau tidak mau penyesuaian diri tersebut perlu dilakukan dengan tujuan untuk mempertahankan eksistensi dan meningkatkan daya saing dengan lembaga pendidikan tinggi lainnya.

Pembelajaran menggunakan jaringan Internet atau e-learning dapat dikembangkan di lembaga pendidikan tinggi berbasis pesantren untuk meningkatkan kemampuan mahasiswa santri dalam memanfaatkan teknologi digital. Lembaga pendidikan pesantren modern telah melakukan pembaharuan secara lebih mendasar karena telah ditemukan beberapa kelemahan pada pendidikan pesantren tradisional yakni kurikulum yang terbatas pada pembelajaran tentang pengetahuan agama, sehingga lulusan pesantren tradisional memiliki keterbatasan ketika bersaing di lapangan kerja yang memiliki syarat agar menguasai pengetahuan umum dan keterampilan dalam teknologi (Nurhakim, 2011). Pemanfaatan teknologi digital dalam pembelajaran merupakan upaya untuk meningkatkan penguasaan teknologi digital para mahasiswa santri.

Pemanfaatan e-learning dalam pembelajaran juga menjadi sebuah inovasi 
dalam menyongsong era society 5.0. UNIDA (Universitas Darussalam) Gontor merupakan instansi perguruan tinggi pesantren (boarding university). Relasi mahasiswa santri di Universitas Darussalam Gontor dengan dunia luar dibatasi dengan berbagai regulasi yang ada, termasuk juga dalam pemanfaatan media digital. Mahasiswa santri semester 1 dan 2 tidak diperbolehkan menggunakan smartphone. Hal ini tentunya menjadi sebuah kebijakan agar mahasiswa baru yang merupakan peralihan dari santri tidak secara bebas berhubungan dengan dunia luar. Pemanfaatan teknologi hanya diperbolehkan dalam kegiatan pembelajaran salah satunya dengan menggunakan e-learning.

Etika komunikasi digital menjadi hal penting yang harus dimiliki mahasiswa santri dalam setiap interaksi melalui media digital. Etika menjadi hal penting yang harus diperhatikan agar tidak menyalahi undangundang yaitu UU ITE. Pengenalan terhadap teknologi digital bagi mahasiswa santri harus dibekali dengan etika sehingga tidak salah dan menimbulkan dampak negatif.

Berdasarkan latar belakang yang ada, penelitian tentang penanaman etika komunikasi digital di pesantren melalui pemanfaatan e-learning menyongsong society 5.0 menjadi pembahasan yang penting dan menarik untuk didiskusikan. Penelitian ini akan memberikan kontribusi terhadap strategi penanaman etika komunikasi digital di Universitas Darussalam Gontor melalui pemanfaatan e-learning menyongsong era society 5.0.

Pemanfaatan e-learning dengan bantuan teknologi informasi dan komunikasi dalam pembelajaran penting dilakukan. Oleh karena itu para dosen di perguruan tinggi pesantren harus mampu mencermati perkembangan model pembelajaran e-learning untuk melahirkan mahasiswa santri yang cakap dalam menggunakan teknologi digital sesuai perkembangan dan kebutuhan zaman. Hal ini karena model pembelajaran menyongsong era society 5.0 harus selalu sesuai dengan kondisi zaman. Di sisi lain, perkembangan model pembelajaran online juga harus diringi dengan etika komunikasi digital. Etika dalam komunikasi digital penting dilakukan sebagai upaya untuk menyongsong era society 5.0 untuk menciptakan kehidupan yang lebih bermakna. Dosen dan mahasiswa santri harus memperhatikan prinsip-prinsip dalam model pembelajaran daring. Hal ini agar pembelajaran e-learning dapat mencapai tujuan yang diinginkan yaitu dapat meningkatkan kemampuan mahasiswa santri dalam memahami konten pembelajaran.

Terdapatbeberapa penelitian terdahuluyang fokus pada pemanfaatan teknologi informasi dan komunikasi dalam dunia pendidikan pesantren. Pada tahun 2012, Sholihah melakukan penelitian tentang peran ICT (Information, Communication and Technologi) dalam modernisasi pendidikan pondok pesantren (Sholihah, 2016). Hasil penelitian menunjukkan bahwa faktor pendorong terjadinya perubahan dalam pembelajaran berupa kekuatan teknologi informasi dan komunikasi. Terdapat banyak keuntungan bagi ustad, santri dan juga pengelola pesantren yang mampu memanfaatkan teknologi informasi dan komunikasi dalam pembelajaran di pesantren. Efisiensi dan efektivitas proses pembelajaran dan pengelolaan pesantren dapat meningkat dengan adanya pemanfaatan teknologi informasi dan komunikasi. Di samping itu, dengan bantuan teknologi informasi dan komunikasi maka dakwah, syiar islam dan pendidikan masyarakat akan semakin luas dan meningkat. Penelitian lain dilakukan oleh Mansur, Husaini, Mujahidin, dan Tafsir yaitu penggunaan TIK di pesantren yang bertujuan untuk meningkatkan model pengajaran karakter kejujuran. Hasil penelitian menunjukkan bahwa penggunaan TIK memiliki pengaruh yang signifikan dalam proses internalisasi nilai-nilai kejujuran. Pemanfaatan TIK dalam pembelajaran menjadi model pengajaran karakter kejujuran. (Mansur, Husaini, Mujahidin, \& Tafsir, 2016).

Penelitian tentang ICT dan pesantren juga pernah dilakukan dengan tema Pemanfaatan TIK di Pesantren Rakyat Sumber Pucung Malang. Hasil penelitian menunjukkan bahwa pembelajaran agama dengan memanfaatkan TIK menjadikan pembelajaran lebih dinamis dan menarik. Pemanfaatan TIK dalam pembelajaran juga mampu menyediakan media dan konten yang lebih beragam (meliputi teks, gambar, audio, video, animasi, dan simulasi). Waktu dan tempat belajar santri menjadi lebih fleksibel. Pemanfaatan TIK dalam pembelajaran di Pesantren Rakyat Sumber Pucung Malang juga diwujudkan dalam bentuk pelatihan bagi para santri dalam membuat konten yang selanjutnya dibagikan melaui Internet (Anwas, 2015). 
Lebih lanjut, penelitian tentang etika komunikasi dalam pembelajaran pernah dilakukan dengan fokus penelitian tentang etika komunikasi mahasiswa (digital natives) kepada dosen melalui media komunikasi Online (WhatsApp) dari perspektif dosen. Hasil penelitian menginformasikan bahwa terdapat hubungan yang lemah antara usia pendidik dengan etika komunikasi mahasiswa yang dilakukan melalui media komunikasi WhatsApp. Dan secara tidak langsung juga menunjukkan bahwa masih terdapat halhal lain yang memiliki hubungan signifikan dengan etika komunikasi peserta didik terhadap pendidik (Fauziyyah, 2019).

Lebih jauh, sejalan dengan beberapa penelitian terdahulu bahwa penelitian ini memiliki tujuan untuk menganalisis strategi penanaman etika komunikasi digital di perguruan tinggi pesantren melalui pemanfaatan e-learning menyongsong era society 5.0. Penelitian tentang etika komunikasi menyongsong era society 5.0 penting dilakukan hal ini karena di era ini lebih mengedepankan konsep kolaborasi teknologi yang berpusat pada manusia atau bisa disebut gabungan antara peran manusia dan pemnafaatan teknologi (Artificial intelligent dan Internet of Things) untuk menyelesaikan permasalahan sosial yang terintegrasi pada ruang nyata dan dunia maya. Dengan kata lain, masyarakat 5.0 adalah masyarakat berbasis teknologi (technology based) yang berpusat pada manusia (humancentered). Konsep society 5.0 lahir sebagai bentuk pengembangan dari era revolusi industri 4.0 yang memiliki potensi dalam mendegradasi peran manusia karena hanya mengandalkan teknologi semata. Etika komunikasi digital menjadi hal urgen yang harus dimiliki setiap orang di era 5.0

Etika komunikasi diekspresikan dalam bentuk sikap tenang, rasa sabar dan empati dalam berkomunikasi yang berasal dari niat tulus, tidak hanya sebatas tutur kata yang baik (Prasanti \& Indriani, 2017). Model komunikasi yang seperti itu dapat mewujudkan suatu interkasi dua arah yang merupakan perwujudan sikap menghargai, memperhatikan, dan saling mendukung antara pihak-pihak yang berkomunikasi. Etika komunikasi merupakan ilmu yang mempelajari tentang baik maupun buruknya cara dalam berkomunikasi. Etika komunikasi mengutamakan sikap jujur dan terus terang, hubungan yang harmonis, ketepatan pesan, menghindari kecurangan, konsistensi antara pesan verbal dan non-verbal, selain itu etika komunikasi juga memberikan perhatian kepada para komunikator terkait sikapnya dalam memotong pembicaraan atau tidak. Oleh karena itu etika komunikasi penting dan harus dimiliki oleh para santri di pondok pesantren agar menjadi role model bagi para remaja dalam berkomunikasi menyongsong era society 5.0.

Pondok pesantren merupakan bentuk lembaga pendidikan berbasis Islam dan bersistem asrama, Kyai menjadi uswah dan sosok panutan, masjid sebagai pusat sarana dalam pengembangan keilmuan dan kemajuan pesantren itu sendiri (Staff Sekretaris PMDGF, 2017). Universitas Darussalam Gontor merupakan perguruan tinggi berbasis pesantren yang menerapkan sistem asrama dan rektor sebagai Kyai yang merupakan figur sentral. Mahasiswa santri tinggal selama 24 jam di dalam kampus. Pembelajaran di Universitas Darussalam Gontor terintegrasi antara pembelajaran mata kuliah dan kehidupan berasrama menjadi suatu sistem yang dinamis. Santri juga dibekali dengan berbagai soft skill melalui pemberian tanggungjawab sebagai staff di biro-biro dan unit usaha yang dimiliki pesantren.

Universitas Darussalam Gontor sebagai perguruan tinggi pesantren memiliki Panca Jiwa yang terdiri dari: (1) Jiwa keikhlasan, menghilangkan semua niat dan keinginan untuk mendapatkan imbalan jasa dalam bentuk material, semuanya untuk memperoleh ridho Allah SWT; (2) Jiwa kesederhanaan, bukanlah berarti pasif dan bukan juga melarat atau miskin, kesederhanaan berarti bersikap tepat dalam situasi dan kondisi yang sesuai pula; (3) Berdikari, pondok pesantren tidak akan menyandarkan keberlangsungannya pada bantuan dari pihak luar, selain itu santri atau mahasiswa dan seluruh civitas pondok pesantren harus selalu belajar dan berupaya mengurus segala kepentingannya sendiri; (4) Ukhuwwah Islamiyyah, yaitu rasa kekeluargaan dan kebersamaan dalam menjalani hidup di pondok maupun diluar pondok pesantren; dan (5) Jiwa bebas, bebas dari pengaruh siapapun karena Gontor berdiri atas dan untuk semua golongan. Mahasiswa santri dilatih agar berpengetahuan luas dan berpikiran bebas, mahasiswa santri juga dilatih agar tidak feodal, tidak egois dan 
peka sosial (Hardoyo, 2008). Hal ini harus diimplementasikan dalam kegiatan berasrama maupun dalam pembelajaran mata kuliah.

Universitas Darussalam Gontor memiliki beberapa kampus cabang yang tersebar di beberapa lokasi. Bantuan teknologi dalam pembelajaran penting untuk dikembangkan sebagai sarana untuk memudahkan proses pembelajaran terutama di kampus-kampus cabang. Paradigma yang berkembang di pesantren adalah bahwa belajar dengan bertemu guru secara langsung merupakan keberkahan, sehingga model pembelajaran kuliah mimbar (ceramah) masih mendominasi. Akan tetapi seiring perkembangan zaman inovasi penting dilakukan salah satunya dengan melakukan model e-learning tanpa meninggalkan model atau metode pembelajaran secara face-to face. Hal ini karena e-learning dapat menjadi suplemen yang sifatnya opsional atau pilihan.

E-learning adalah model pembelajaran dengan memanfaatkan teknologi informasi dan komunikasi berbasis Internet. Sistem E-learning bukan hanya menggantikan tetapi diharapkan juga menjadi alternatif media pembelajaran tradisional seperti buku, diskusi dalam kelas, dan pelatihan komputer non-Internet. Sistem E-learning memiliki berbagai elemen yang terdapat didalamnya yaitu: (1) Materi kuliah yang disajikan dengan power point yang berisi poin-poin materi kuliah namun disajikan dengan tampilan yang menarik, ditambah gambar, suara, dan video; (2) Beragam soal yang berisi pertanyaan untuk evaluasi pembelajaran. Soal yang disediakan lengkap dengan kunci jawaban dan skor akhir sehingga mahasiswa dapat mengukur penguasaan terhadap materi; (3) Para mahasiswa dapat mengembangkan komunitas online untuk mendapatkan berbagai referensi yang dibutuhkan dalam menambah pengetahuan; (4) Para dosen dapat berperan aktif dan terlibat dalam diskusi dengan para mahasiswa; (5) Terdapat perangkat lunak yang mendukung sehingga kuliah daring dapat dilakukan real time dan dalam waktu yang sama, sehingga jarak tidak lagi menjadi kendala; dan (6) Pemanfaatan platform multimedia berupa audio dan video yang lebih menarik dalam penyemapian materi pembelajaran.

Bagi lembaga pendidikan tinggi dan institusi yang telah memiliki kelengkapan fasilitas jaringan komputer, pemanfaatan e-learning diharapkan mampu menjadi penunjang dalam meningkatkan mutu pendidikan. Salah satu peningkatan mutu pendidikan tinggi dapat didorong melalui pengembangan sistem e-learning. Keberadaan e-learning dapat menghadirkan pembelajaran dengan kriteria: (1) jaringan yang memiliki kemampuan untuk memperbaharui, menyimpan, mendistribusikan serta membagikan materi ajar berbasis TIK; (2) pengiriman kepada pengguna terakhir melalui jaringan komputer melalui teknologi Internet yang standar; dan (3) memfokuskan pada suatu pandangan dan paradigma pembelajaran yang tidak lagi tradisional (Rosenberg \& Foshay, 2002).

Tujuan dari pengembangan sistem pembelajaran berbasis Internet atau e-learning di Prodi Ilmu Komunikasi UNIDA Gontor adalah untuk memudahkan proses pembelajaran bagi dosen dan mahasiswa. Proses pembelajaran seperti ini dapat dilakukan secara real time dan dimana saja. Interaksi virtual dengan memanfaatkan teknologi informasi tidak mengharuskan peserta ajar (mahasiswa) duduk di satu ruangan untuk mendapatkan materi. E-learning merupakan pengajaran intern yang membantu pengajar memanfaatkan waktu, fasilitas, teknologi dalam upaya untuk meningkatkan proses pembelajaran. Pemahaman mahasiswa dapat ditingkatkan melalui inovasi dan pengembangan pembelajaran berbasis e-learning. Pembelajaran e-learning mampu menyajikan bentuk materi yang bervariasi, tidak hanya tekstual saja tetapi materi yang berupa visual berupa image, video dan juga animasi. Hal ini dapat memperjelas pemahaman mahasiswa terhadap materi. Keberhasilan dari program pembelajaran ini dapat dilihat dari meningkatnya pemahaman mahasiswa terhadap mata kuliah yang di e-learning-kan. Secara spesifik, penelitian ini bertujuan untuk menganalisis penanaman etika komunikasi digital di pesantren melalui pemanfaat $e$-learning.

\section{METODE PENELITIAN}

Penelitian tentang penanaman etika komunikasi digital penting dilakukan sebagai salah satu upaya untuk mendukung kebijakan Dirjen Bimas Islam Kemenag RI tentang Tujuh Standar Literasi Media Islam Online. Jenis penelitian ini adalah kualitatif untuk mengkaji strategi penanaman etika komunikasi digital di 
lembaga pendidikan tinggi pesantren melalui pemanfaatan e-learning dalam menyongsong era society 5.0. Pengumpulan data dalam penelitian ini dilakukan melalui observasi, wawancara dan dokumentasi. Wawancara mendalam dilakukan kepada para stake holder di Prodi Ilmu Komunikasi UNIDA Gontor, prodi ini menjadi uji coba pengembangan konten pembelajaran e-learning. Wawancara juga dilakukan kepada mahasiswa sebagai objek uji coba pembelajarn e-learning. Observasi dilakukan dengan mengamati kegiatan uji coba pembelajaran e-learning khususnya yang berkaitan dengan etika komunikasi melalui jaringan digital. Dokumentasi digunakan untuk mengumpulkan berbagai referensi yang tertulis dan data-data tentang fokus penelitian.

Setelah melakukan pengumpulan data, peneliti mengonstruksi pesan-pesan yang diperoleh dan memetakan strategi penanaman etika komunikasi digital di lembaga pendidikan tinggi pesantren. Teori Miles dan Huberman menjadi teknik analisis data dalam penelitian yang terdiri dari tahapan yaitu reduksi, display data, dan konklusi menurut interpretasi peneliti (Tamin, 2011). Triangulasi sumber dan metode digunakan untuk mengukur keabsahan data penelitian. Triangulasi adalah suatu cara mendapatkan data yang benar-benar absah dengan menggunakan metode ganda (Bachri, 2010). Triangulasi sumber yaitu dengan melakukan penggalian informasi kepada beberapa informan dan triangulasi metode melalui beberapa teknik koleksi data yaitu wawancara mendalam (in-dept interview), pengematan dan dokumentasi data. Wawancara mendalam dilakukan kepada para pemangku kebijakan di Universitas Darussalam Gontor, pengampu mata kuliah dasar dan mahasiswa. Observasi dilakukan melalui pengamatan aktivitas pembelajaran e-learning, sedangkan dokumentasi dilakukan dengan mengumpulkan data-data terkait dengan tema penanaman etika komunikasi digital melalui pemanfaatan e-learning.

\section{HASIL DAN PEMBAHASAN}

Tujuan penelitian ini adalah untuk menganalisis strategi penanaman etika komunikasi digital melalui e-learning di Universitas Darussalam Dontor. Untuk mengetahui strategi penanaman etika komunikasi digital di lembaga pendidikan tinggi pesantren menyongsong era masyarakat 5.0, dalam penelitian ini akan dikaji berdasarkan kriteria Dirjen Bimas Islam Kemenag RI berupa standar literasi media islam online. Adapun kriteria tersebut terdiri dari tujuh standar yaitu 1) prinsip dalam memproduksi pesan, 2) etika mendistribusikan informasi, 3) menjamin adanya akurasi dan komitmen anti hoak, 4) adanya semangat amar ma'ruf nahi munkar, 5) azas hikmah dalam dakwah, 6) prinsip dalam interaksi virtual, dan 7) prinsip kebebasan (Kementerian Agama Republik Indonesia, 2017).

Strategi penanaman etika komunikasi digital menggunakan e-learning di UNIDA Gontor dapat diilustrasikan dalam gambar 1.

Penanaman etika komunikasi digital melalui e-learning yang diilustrasikan dalam gambar 1 memberikan informasi bahwa kegiatan pembelajaran dilakukan oleh dosen sebagai komunikator untuk menyampaikan materi kuliah melalui media berupa e-learning kepada mahasiswa santri sebagai komunikan. Tujuh standar literasi media islam online merupakan standar yang dapat diimplementasikan untuk menanamkan etika komunikasi digital melalui e-learning yang merupakan proses pembelajaran dengan bantuan TIK berupa new media atau Internet. Tujuh standar tersebut meliputi prinsip produksi berita online berupa materi kuliah, etika distribusi berita yaitu penyampaian materi kuliah, jaminan akurasi dan mengindari hoax, prinsip ajakan kebaikan dan mencegah kemungkaran (amar ma'ruf nahi munkar), prinsip kebijaksanaan (hikmah) dalam dakwah, prinsip hubungan virtual (interaksi digital), dan prinsip kemerdekaan atau kebebasan.

Penjelasan tentang tujuh standar literasi media islam online dalam e-learning disajikan pada tabel 1 .

Standar pertama prinsip produksi konten adalah langkah verifikasi (tabayyun) akurasi informasi dan cermat memeriksa kredibilitas narasumber. Dalam pembelajaran e-learning di Universitas Darussalam Gontor, mahasiswa santri harus selalu melakukan verifikasi konten pembelajaran dengan cara yang cermat. Dalam melakukan diskusi dan memenuhi tugas kuliah daring serta menjawab quiz, mahasiswa santri juga harus melakukan berbagai kajian pustaka sebagai bentuk verifikasi atau tabayyun sumber informasi yang diperoleh. Lebih 


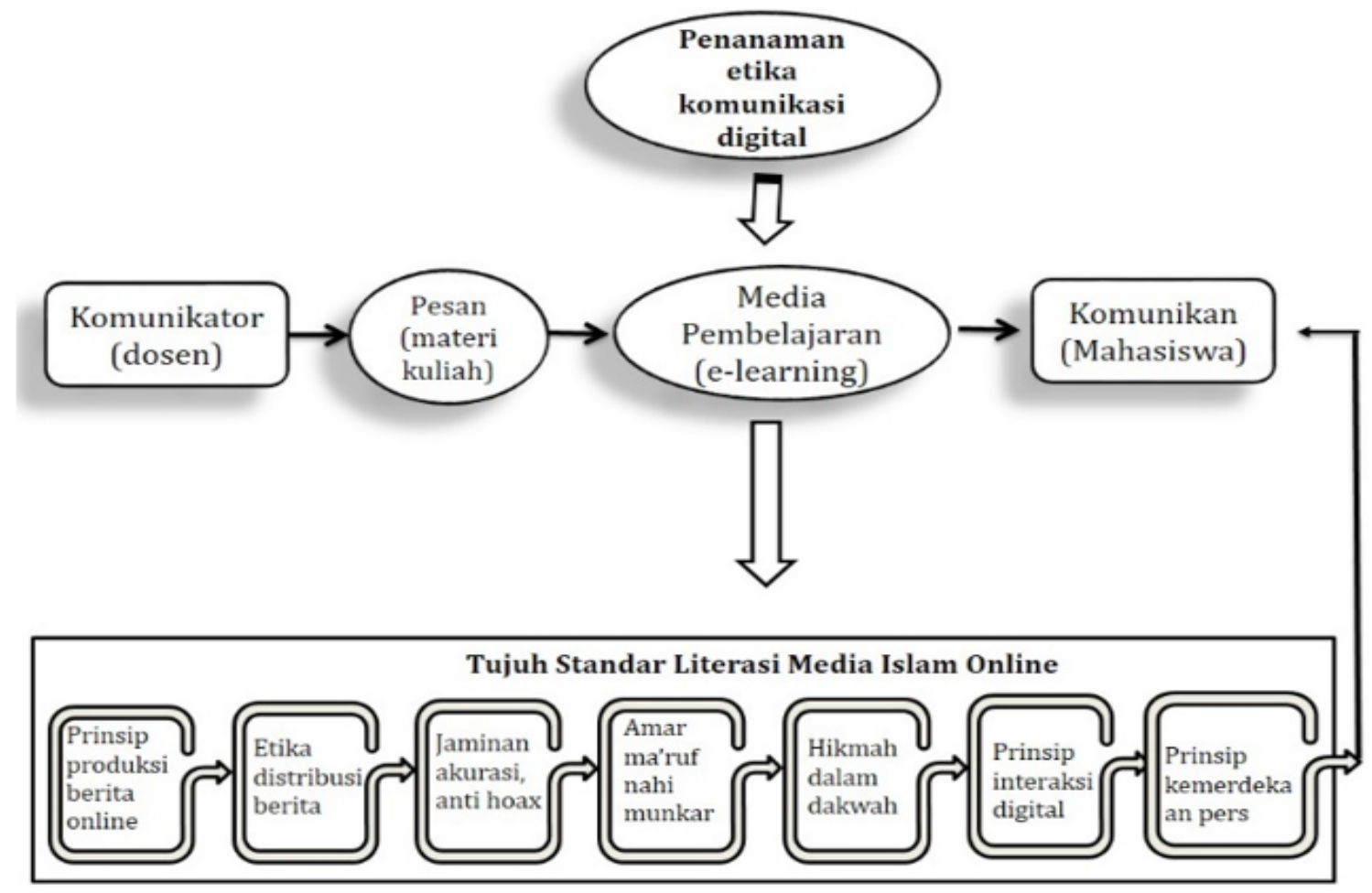

Sumber: Hasil Penelitian, 2019

Gambar 1 Penanaman Etika Komunikasi Digital Melalui E-learning

lanjut, mahasiswa juga dituntut untuk selalu mencantumkan sumber referensi yang valid dalam setiap tugas yang di kumpulkan, hal ini juga sebagai bentuk pencegahan plagiasi karya tulis ilmiah. Ini sejalan dengan penelitian yang menyatakan bahwa salah satu hal yang solutif bagi generasi millenial dalam mencegah dampak negatif globalisasi adalah melalui pengkajian ulang berbagai informasi dan selalu berupaya berpikir kritis (Walidah, 2018). Termasuk juga dalam melakukan tabayyun atau verifikasi dan cross-check dalam melakukan produksi pesan dalam proses pembelajaran.

Langkah ini juga sebagai upaya untuk meningkatkan kredibilitas mahasiswa santri tersebut dan sebagai bentuk pemenuhan etika komunikasi digital dalam proses pembelajaran daring melalui e-learning. Hal ini sejalan dengan penelitian tentang upaya membangun budaya tabayyun dalam keilmuan islam melalui studi kritis konsep sanad kitab Najh AlBalaghah (Bashori, 2016). Dalam penelitian ini dinyatakan bahwa untuk menghindari perbuatan yang salah, berbuat zalim dan penyesalan maka yang dapat dilakukan adalah verifikasi (tabayyun atau tahaqquq) dan konfimasi (taakkud) terhadap berita atau informasi. Salah satu rekomendasi penelitiannya adalah agar membiasakan dan membudayakan kegiatan tabayyun ilmiah.

Prinsip produksi konten tersebut telah ditekankan kepada mahasiswa pada saat uji coba e-learning. Secara umum mahasiswa telah melakukan prinsip tersebut meskipun belum maksimal. Kebiasaan ini perlu untuk terus di biasakan agar membudaya dan pada akhirnya terbiasa. Hal ini sejalan dengan pendidikan di pesantren, yaitu santri terbiasa karena dipaksa. Sebagai upaya untuk menjaga karya ilmiah yang bebas plagiat, Universitas Darussalam Gontor menyediakan software Turnitin. Upaya ini dilakukan agar setiap karya, baik karya dosen maupun mahasiswa, terbebas dari plagiasi. Disamping itu juga membiasakan mahasiswa untuk berpikir kritis dan tidak hanya copy-paste ide dan gagasan orang lain tanpa mencantumkan referensi dengan tepat.

Standar kedua etika distribusi informasi adalah memastikan bahwa informasi yang akan disebarluaskan mampu memberikan kebermanfaatan dan tidak menimbulkan perdebatan. Dalam penelitian ini, dosen sebagai subjek penelitian selalu memastikan 
Tabel 1 Tujuh Standar Literasi Media Islam Online Dalam E-learning

\begin{tabular}{|c|c|c|}
\hline Standar & Prinsip & Penjelasan \\
\hline 1 & Produksi & $\begin{array}{l}\text { Produksi atau } \\
\text { penyusunan } \\
\text { materi kuliah dan } \\
\text { tugas }\end{array}$ \\
\hline 2 & Etika distribusi & $\begin{array}{l}\text { Penyampaian } \\
\text { materi dan tugas } \\
\text { mahasiswa harus } \\
\text { sesuai etika } \\
\text { komunikasi dalam } \\
\text { islam }\end{array}$ \\
\hline 3 & $\begin{array}{l}\text { Jaminan } \\
\text { akurasi }\end{array}$ & $\begin{array}{l}\text { Ketepatan materi } \\
\text { dan tugas }\end{array}$ \\
\hline 4 & $\begin{array}{l}\text { Amar ma'ruf } \\
\text { nahi munkar }\end{array}$ & $\begin{array}{l}\text { Materi dan tugas } \\
\text { mahasiswa } \\
\text { betujuan untuk } \\
\text { mengajak } \\
\text { kebaikan }\end{array}$ \\
\hline 5 & Hikmah & $\begin{array}{l}\text { Kebermanfaatan } \\
\text { perkuliahan }\end{array}$ \\
\hline 6 & $\begin{array}{l}\text { Interaksi } \\
\text { digital }\end{array}$ & $\begin{array}{l}\text { Berkaitan dengan } \\
\text { etika komunikasi } \\
\text { melalui } \\
\text { media daring } \\
\text { (e-learning) }\end{array}$ \\
\hline 7 & Kemerdekaan & $\begin{array}{l}\text { Kebebasan dalam } \\
\text { menyampaikan } \\
\text { pendapat }\end{array}$ \\
\hline
\end{tabular}

Sumber: Hasil Penelitian, 2019

kebermanfaatan informasi dan materi yang disampaikan melalui e-learning. Langkah yang dilakukan berupa penyusunan silabus dan satuan acara perkuliahan yang di sahkan oleh ketua program studi, dan selalu di evaluasi pada akhir perkuliahan sehingga dapat diketahui bahwa para mahasiswa santri dapat memperoleh kebermanfaatan dari materi yang disampaikan.

Di samping itu, sebagai upaya penanaman etika komunikasi digital, mahasiswa santri juga diwajibkan untuk memastikan berbagai informasi yang dibagikan secara daring melalui e-learning, apakah mata kuliah yang diikuti benar-benar membawa kemanfaatan dan benar. Mahasiswa santri memiliki hak untuk melakukan penilaian terhadap kinerja dosen dalam mata kuliah yang diikuti mahasiswa yang bersangkutan. Evaluasi kinerja dosen secara otomatis terintegrasi dalam SIAKAD (Sistem Informasi Akademik), mahasiswa tidak akan dapat melihat nilai mata kuliah sebelum melakukan penilaian terhadap dosen pengampu mata kuliah. Melalui mekanisme tersebut terdapat proses komunikasi timbal balik, dimana mahasiswa dan dosen berkewajiban menyampaikan informasi yang benar dan bermanfaat, juga memiliki hak untuk saling menilai atau mengkritisi proses penyampaian informasi serta konten yang disampaikan. Dosen dan mahasiswa dituntut untuk memperhatikan masalah etis dalam berkomunikasi khususnya dalam proses pembelajaran daring. Berkaitan dengan masalah etis dalam media online (Margianto \& Syaefullah, 2006) disampaikan bahwa pada ranah etis kemunculan dan keberadaan Internet sebagai new media memicu munculnya ketegangan baru. Untuk mengurangi ketegangan di ranah etis maka etika distribusi informasi melalui pembelajaran e-learning penting untuk diterapkan.

Berkaitan dengan prinsip etika distribusi informasi, dapat juga dikaitkan dengan etika komunikasi islam. Adapun dalam Islam istilah atau 'konteks' komunikasi diantaranya terdapat dalam lafadz "Qaulan" (perkataan). Ada 6 istilah 'perkataan' atau Qaulan yang menjadi pedoman berkomunikasi menurut Islam: Qaulan Sadida (perkataan yang benar), Qaulan Baligha (perkataan yang berdampak atau efektif), Qaulan Ma'rufa (perkataan yang baik), Qaulan Karima (ucapan yang mulia), Qaulan Layina (lemah lembut), Qaulan Maisura (perkataan yang mudah dipahami). Dalam konteks pembelajaran e-learning di Universitas Darussalam Gontor, dosen maupun mahasiswa harus mampu memahami etika komunikasi. Pembelajaran daring antara dosen dan mahasiswa membatasi proses komunikasi secara langsung, hal ini harus menjadi perhatian karena makna pesan yang ditulis melalui media daring dapat menimbulkan interpretasi yang berbeda-beda. Dosen dan mahasiswa di UNIDA Gontor sebagai sebuah lembaga perguruan tinggi berbasis pesantren harus mampu mengimplementasikan konsep etika komunikasi Islam dalam pembelajaran daring melalui e-learning.

Berdasarkan hasil wawancara diketahui bahwa menjadi tantangan tersendiri bagi dosen dalam pembelajaran e-learning, dosen harus mampu mengemas materi pembelajaran dengan 
lebih kreatif dan inovatif sehingga pesan berupa materi pembelajaran e-learning yang dimaksud dapat tersampaikan dan mahasiswa dapat memahami maksud pesan yang ada. Dosen di Universitas Darussalam Gontor belum terbiasa dengan pembelajaran e-learning sehingga perlu adanya penyesuaian serta pendampingan dalam mengembangkan pembelajaran e-learning.

Standar ketiga jaminan akurasi dan komitmen anti hoak adalah menjamin kejujuran informasi ditengah informasi dusta, hoax, dan manipulatif. Hoax mempunyai relasi dengan Hocus yang memiliki arti 'menipu' dan 'memaksa'. Hoax bersifat memanipulasi dan menipu dan memiliki atribusi negatif (Gumilar, 2017). Dosen di UNIDA Gontor telah memiliki komitmen untuk menyebarkan informasi yang akurat dan menghindari segala bentuk hoax. Materi yang di sampaikan melalui e-learning merupakan informasi yang mengandung kejujuran.

Pada sisi mahasiswa santri, penanaman etika komunikasi digital melalui prinsip akurasi dan jaminan anti hoax dilakukan dengan membiasakan mahasiswa untuk mencantumkan sumber referensi ketika mengerjakan tugas mata kuliah e-learning. Hal ini sebagai upaya untuk meningkatkan kejujuran dan mengurangi informasi yang tidak valid dalam pembelajaran. Dalam konteks pembelajaran di pesantren prinsip kejujuran harus diutamakan di lingkungan mahasiswa santri. Berbagai peraturan dibuat untuk mendisiplinkan mahasiswa santri termasuk dalam menjalankan prinsip kejujuran. Mahasiswa santri yang tidak jujur akan dikenai sanksi, baik secara sosial maupun peraturan tertulis. Hal ini berlaku juga dalam proses pembelajaran e-learning.

Dosen menyusun kontrak kuliah diawal pertemuan semester. Hal-hal yang berhubungan dengan pembelajaran dibahas dalam pertemuan daring. Hal penting yang tidak terlupakan berkaitan dengan prinsip kejujuran, yaitu mahasiswa diwajibkan jujur dalam memenuhi berbagai tugas, tidak boleh mencontek atau bahkan copy-paste dari Internet. Dosen tidak akan segan mencekal (tidak meluluskan) mahasiswa dalam mata kuliah jika diketahui telah melanggar prinsip kejujuran. Kontrak kuliah menjadi salah satu cara untuk menanamkan prinsip akurasi dan anti hoax dalam melaksanakan pembelajaran e-learning.

Standar keempat semangat amar ma'ruf nahi munkar adalah melakukan kontrol untuk menyeru kebajikan dan mencegah kemungkaran. Mahasiswa santri UNIDA Gontor memiliki semangat menyeru kebajikan dan mencegah kemungkaran dalam semua kegiatan di asrama dan di lingkungan kampus baik di kelas maupun di luar kelas. Dalam kegiatan pembelajaran melalui e-learning, materi yang disampaikan dosen merupakan materi umum yang dipadukan dengan worldview Islam, sehingga spirit amar ma'ruf nahi munkar merupakan tujuan utama dalam kegiatan pembelajaran dengan goal perubahan sosial. Worldview Islam menjadi ciri khas pembelajaran di UNIDA Gontor, yaitu semua mata kuliah diarahakan pada islamisasi ilmu pengetahuan. Mahasiswa diajarkan berbagai teori dan konsep tentang islamisasi ilmu pengetahuan dalam proses pembelajaran. Demikian juga ketika di luar kelas, mahasiswa santri dituntut untuk mengaplikasikan perilaku hidup Islami.

Untuk mewujudkan islamisasi ilmu pengetahuan dan praktik kehidupan Islami, UNIDA Gontor memiliki Panca Jiwa yang meliputi keikhlasan, kesederhanaan, berdikari, ukhuwah islamiyah, dan jiwa bebas. Dengan berpegang pada Panca Jiwa inilah mahasiswa santri akan mampu mengaplikasikan pinsip amar ma'ruf nahi munkar dalam kehidupan, termasuk juga dalam praktik pembelajaran melalui e-learning.

Strategi dan metode pembelajaran juga disesuaikan dengan kondisi zaman saat ini, dalam penelitian ini berupa pembelajaran melalui media daring e-learning. Hal ini sejalan dengan penelitian tentang dakwah dan perubahan sosial. Hasil penelitian menunjukkan bahwa agar fungsi dakwah dapat berjalan dengan efektif yang harus diterapkan adalah inovasi metode dan strategi sesuai dengan kondisi sosial yang ada dalam masyarakat, dengan langkah ini umat akan terbentengi dari pengaruh-pengaruh negatif yang diakibatkan oleh kondisi masyarakat yang mengalami perubahan sosial (Amran, 2012).

Dalam konteks penelitian ini, prinsip seruan kepada kebajikan dan mencegah kemungkaran ditanamkan dengan diskusi dalam forum e-learning, dimana tujuan diskusi adalah untuk menyampaiakan ide dan gagasan dengan cara yang baik sehingga tidak memunculkan ketegangan bahkan yang biasa disebut dengan debat kusir atau debat yang hanya ingin saling 
menjatuhkan. Proses diskusi antar mahasiswa dan dosen melalui media e-learning harus tetap bertujuan untuk amar ma'ruf nahi munkar, saling bertukar ide dan gagasan untuk menambah wawasan dan memperkaya pengetahuan. Penyampaian informasi serta cara menjawab pertanyaan dalam forum diskusi online harus tetap terkontrol. Dosen membuat aturan tersendiri terkait metode diskusi online ini, hal ini bertujuan agar diskusi tidak hanya sekedar unjuk diri tetapi benar-benar menyampaikan konten yang bermanfaat.

Standar kelima asas hikmah atau kebijaksanaan dalam dakwah adalah mengutamakan sikap bijaksana, penuh hikmah, keteladanan atau uswah hasanah, jika harus berdebat maka dilaksanakan dengan sikap yang lebih baik. Mahasiswa santri UNIDA Gontor sudah berusaha untuk menjadi uswah hasanah atau contoh yang baik untuk temantemannya, menasehati dengan cara yang baik. Dalam konteks pembelajaran online banyak hal yang telah dicontohkan misalnya menghindari plagiarisme, disiplin dalam pembelajaran, dan lain-lain. Hal ini sebagaimana penelitian tentang dakwah di era informasi dan globalisasi dengan kebijaksanaan kepada masyarakat modern (Ghafur, 2014). Menurut Ghafur, gerakan dakwah di era informasi dan globalisasi sudah mampu memberikan konten secara modern berbasis teknologi informatika dan bukan hanya secara konvensional-tradisional, sehingga mampu menyuguhkan isi yang sesuai kebutuhan dan tantangan masyarakat modern serta sifat dakwahnya mampu melintasi batas ruang dan waktu.

Dalam penelitian ini, upaya yang telah dilakukan dosen dalam menanamkan etika komunikasidigitalmelaluiprinsiphikmahadalah dengan membiasakan mahasiswa bersikap bijak dalam pembelajaran e-learning. Bersikap bijak dalam pembelajaran dapat ditunjukkan dengan kedisiplinan mahasiswa dalam mengikuti perkuliahan daring. Mengerjakan tugas tepat waktu, berdiskusi dengan cara yang baik, juga menjawab soal kuis dengan cara yang tepat dan tidak asal menjawab.

Berdasarkan hasil wawancara diketahui bahwa untuk membiasakan penerapan prinsip hikmah dalam pembelajaran e-learning, dosen telah terlebih dahulu menyampaikan berbagai kriteria penilaian pada awal semester melalui kontrak kuliah. Dosen telah menyepakati bersama mahasiswa terkait kriteria penilaian untuk tugas, keaktifan diskusi, jawaban untuk kuis dan sebagainya. Dosen akan memberikan nilai tambah bagi mahasiswa yang disiplin dalam mengerjakan tugas, aktif dalam forum diskusi dan quiz. Dalam hal ini dosen membelakukan konsep reward and punishment. Dalam konteks pesantren model reward dan punishment dinilai efektif untuk mendisplinkan mahasiswa agar mampu bersikap bijak dan penuh hikmah.

Standar keenam prinsip interaksi digital atau hubungan secara virtual adalah sikap saling menghormati dan semangat untuk saling menolong (ta'awun). Dalam konteks UNIDA Gontor, seluruh mahasiswa santri telah terbiasa untuk saling menghormati dan membantu satu dengan lainnya. Sikap menghormati dan membantu dalam proses pembelajaran melalui e-learning dapat ditunjukkan dengan adanya forum diskusi yang menyediakan kesempatan seluas-luasnya untuk saling bertukar pendapat. Respek merupakan salah satu nilai spiritual yang penting untuk dikembangkan di berbagai kelompok masyarakat.

Membantu dalam konteks pembelajaran e-learning adalah saling bertukar pikiran tentang materi perkuliahan melalui forum diskusi dengan tetap bersikap saling menghormati satu sama lain. Dosen telah menyampaikan kepada mahasiswa di kontrak kuliah bahwa prinsip pembelajaran e-learning yaitu kebermanfaatan sehingga melalui pembelajaran daring ini dosen dan mahasiswa dapat bertukar pikiran khususnya terkait materi yang dibahas. Adanya forum diskusi juga memberikan kesempatan belajar bersikap hormat melalui cara penyampaian yang baik, selain itu juga menanamkan prinsip membantu dengan adanya kemauan memberikan informasi yang benar dalam proses diskusi dalam forum e-learning.

Dosen juga telah memberikan pemahaman kepada mahasiswa bahwa kebebasan berekspresi di e-learning berbeda dengan cara ekspresi diri di media sosial. Pembelajaran e-learning membiasakan mahasiswa untuk mampu mengendalikan diri ketika berinteraksi melalui media sosial dan media daring lainnya. Dengan terbiasa untuk mampu mengendalikan diri maka mahasiswa santri akan belajar cara berinteraksi yang baik ketika di dunia maya.

Standar ketujuh prinsip kebebasan adalah menyampaikan informasi dengan cara mengekspresikan secara bertanggungjawab 
dengan berpegang pada prinsip 'the best human being is the most beneficial for fellow human beings'. Dalam konteks di UNIDA Gontor, proses pembelajaran dilakukan dengan bebas tetapi tetap secara bertanggungjawab dan bertujuan untuk memberikan keberkahan bagi orang lain. Hal ini sebagaimana disampaikan bahwa media online memberikan kebebasan dalam mengeluarkan pendapat bagi setiap individu yang terlibat di dalamnya. Akan tetapi supaya kebebasan orang lain tidak terganggu maka setiap individu juga harus mengedepankan sikap kendali diri (Watie, 2016).

Prinsip kebebasan telah menjadi fondasi atau asas nilai pendidikan di Universitas Darussalam Gontor sebagaimana tercantum dalam panca jiwa. Kebebasan dalam panca jiwa gontor memiliki makna hak asasi manusia untuk melakukan segala tindakan dalam bentuk hak merdeka, sesuai kehendak pribadi asalkan tidak mengganggu kepentingan orang lain, dan yang jauh lebih penting lagi adalah tidak bertentangan dengan syari'ah (Supriadi, 2016). Kebebasan dalam mencari ilmu sebanyakbanyaknya, kebabasan dalam diskusi dan sebagainya. Dalam pembelajaran e-learning prinsip kebebasan dapat ditunjukkan dengan keluasan kesempatan dalam diskusi forum secara daring dengan tetap memperhatikan hak-hak orang lain. Penyampaian diskusi tidak menyinggung perasaan orang lain atau bahkan menyakiti hati mahasiswa lain. Bebas yang dimaksud tetap pada bingkai aturan syariat serta nilai-nilai Pondok Modern Darussalam Gontor. Penanaman prinsip kebebasan dalam pembelajaran e-learning juga dapat dilakukan melalui pemberian kesempatan yang luas kepada mahasiswa untuk mengutip berbagai referensi dalam menyusun makalah atau pun tugas.

Penanaman etika komunikasi di lingkungan pesantren bukanlah hal baru, termasuk diUNIDA Gontor. Hal ini karena etika komunikasi islam telah sejak lama menjadi materi pendidikan di lingkungan Universitas Darussalam Gontor. Etika komunikasi tidak hanya diajarkan dalam kelas tetapi juga dicontohkan oleh para kyai dan dosen. 'Apa yang kamu lihat, kamu dengar, dan kamu rasakan adalah pendidikan', hal ini mengandung makna bahwa apa saja yang diperbuat dan disampaiakan dosen adalah pendidikan yang harus dicontoh oleh para mahasiswa santri. Penanaman etika komunikasi yang dilakukan secara langsug tidaklah menjadi suatu kendala.

Dengan perkembangan teknologi dan era digital menyongsong society 5.0, penanaman etika komunikasi digital menjadi tantangan tersediri dalam dunia pendidikan pesantren. Hal ini karena tantangan dan tuntutan media digital semakin banyak, di samping itu feedback komunikasi melalui media daring tidak dapat secara langsung tersampaikan, bahkan seringkali terjadi miscommunication karena salah interpretasi makna pesan. Oleh karena itu e-learning menjadi sarana yang tepat dalam menanamkan etika komunikasi digital kepada para mahasiswa santri sehingga pada akhirnya terbiasa untuk berinteraksi melalui media daring dengan tetap menjunjung tinggi etika komunikasi digital.

Penelitian ini menemukan sebuah strategi penanaman etika komunikasi digital di perguruan tinggi pesantren menyongsong era society 5.0. Penanaman etika komunikasi digital melibatkan tujuh standar literasi media Islam daring yang terdiri dari prinsip produksi berita daring, etika distribusi berita, jaminan akurasi dan komitmen anti hoax, semangat amar ma'ruf nahi munkar, asas kebijaksanaan dalam dakwah, prinsip dalam interaksi digital, dan prinsip kebebasan atau kemerdekaan pers. Ketujuh standar telah diterapkan meskipun belum secara maksimal, hal ini karena pembelajaran e-learning di Universitas Darussalam Gontor juga masih dalam tahap uji coba dan belum secara penuh diterapkan. Kontribusi penelitian ini berupa strategi penanaman etika komunikasi digital di lembaga pendidikan pesantren menyongsong era society 5.0. Penelitian tentang efektivitas strategi penanaman etika komunikasi digital di perguruan tinggi pesantren melalui e-learning perlu dilakukan untuk mengukur apakah strategi yang diterapkan dapat diimplementasikan dengan baik. Rekomendasi penelitian juga ditujukan bagi para mahasiswa santri untuk melaksanakan standar literasi media Islam daring dalam kegiatan pembelajaran e-learning dan bagi UNIDA Gontor untuk terus melakukan inovasi media pembelajaran untuk memperkuat eksistensinya dalam menyongsong era society 5.0.

\section{SIMPULAN}

Penelitian ini menganalisis sebuah strategi 
penanaman etika komunikasi digital di UNIDA Gontor sebagai sebuah lembaga perguruan tinggi berbasis pesantren melalui pemanfaatan e-learning menyongsong era society 5.0. Strategi penanaman etika komunikasi digital di UNIDA Gontor melalui pemanfaatan e-learning yang dilakukan berdasarkan standar literasi media Islam daring. Terdapat 7 standar literasi media islam daring sebagai rujukan dalam menanamkan etika komunikasi digital kepada para mahasiswa santri. Ketujuh standar tersebut terdiri dari prinsip dalam memproduksi konten, etika distribusi informasi, jaminan akurasi dan komitmen anti hoax, semangat menyeru kepada kebajikan dan mencegah kemungkaran, asas kebijaksanaan dalam dakwah, prinsip dalam interaksi digital, dan prinsip kemerdekaan atau kebebasan. Ketujuh standar literasi media islam online sudah diterapkan dalam pembelajaran untuk menanamkan etika komunikasi digital meskipun belum secara maksimal. Pembelajaran e-learning mata kuliah dasar ilmu komunikasi menjadi sarana dalam menanamkan etika komunikasi digital menyongsong era society 5.0. Melalui pembelajaran e-learning mahasiswa santri dibiasakan untuk melakukan interaksi secara daring dengan menerapkan etika komunikasi digital sesuai standar yang telah ditetapkan oleh prodi dan para dosen yang mengampu mata kuliah. Kontribusi penelitian ini berupa strategi penanaman etika komunikasi digital melalui pemanfaatan e-learning di lembaga pendidikan tinggi berbasis pesantren. Rekomendasi penelitian ini berupa strategi penanaman etika komunikasi digital melalui pemanfaatan e-learning yang dapat diimplementasikan di perguruan tinggi berbasis pesantren.

\section{DAFTAR PUSTAKA}

Amran, A. (2012). Dakwah dan perubahan sosial. HIKMAH, 6(1), 68-86. Retrieved from https://www.google.com/url?sa $=\mathrm{t} \& \mathrm{rct}=\mathrm{j} \& \mathrm{q}=\&$ esrc $=\mathrm{s} \&$ source $=\mathrm{web} \&$ $c d=1 \& c a d=$ rja $\&$ uact $=8 \&$ ved $=2$ ahUK EwiKrM-C98TnAhVYaCsKHeDRA 4QFjAAegQIBBAB\&url=http $\% 3 \mathrm{~A}$ $\% 2 \mathrm{~F} \% 2$ Frepo.iain-padangsidimpuan. ac.id $\% 2$ F202\%2F1\%2FAli\%2520Amran1. $\mathrm{g}=\mathrm{AOvVaw} 388 \mathrm{ELhMZ7vAt0ZERGa5vID}$

Anwas, O. M. (2015). Pemanfaatan teknologi informasi dan komunikasi pada pesantren rakyat Sumber Pucung Malang. Jurnal Pendidikan Dan Kebudayaan, 21(3), 207-220. https://doi.org/10.24832/jpnk. v21i3.187

Bachri, B. S. (2010). Meyakinkan validitas data melalui triangulasi pada penelitian kualitatif. Jurnal Teknologi Pendidikan, 10(1), 46-62. Retrieved from http:// ejournal.unesa.ac.id/index.php/jurnal_tp/ article/view/5006

Bashori, A. H. (2016). Studi kritis konsep sanad kitab Nahj Al-Balaghah sebagai upaya membangun budaya tabayyun dalam keilmuan Islam. El-Harakah, 18(2), 163-183. https://doi.org/10.18860/ el.v18i2.3658

Fauziyyah, N. (2019). Etika komunikasi peserta didik digital natives melalui media komunikasi online (whatsapp) kepada pendidik: Perspektif dosen. PEDAGOGIK: Jurnal Pendidikan, 6(2), 437-474. Retrieved from https://ejournal.unuja.ac.id/ index.php/pedagogik/article/view/750

Ghafur, W. A. (2014). Dakwah bil-hikmah di era informasi dan globalisasi berdakwah di masyarakat baru. Jurnal Ilmu Dakwah, 34(2), 236-258. https://doi.org/http:// dx.doi.org/10.21580/jid.v34.2.69

Gumilar, G. (2017). Hoax, reproduksi dan persebaran: Suatu penelusuran literatur. Jurnal Pengabdian Kepada Masyarakat, 1(4), 271-278. Retrieved from http://jurnal. unpad.ac.id/pkm/article/view/16409

Hardoyo, H. (2008). Kurikulum tersembunyi Pondok Modern Darussalam Gontor. AtTa'dib, 4(2), 191-208. https://doi.org/http:// dx.doi.org/10.21111/at-tadib.v4i2.590

Kementerian Agama Republik Indonesia. (2017). Pertemuan awak media Islam sepakati 7 standar literasi media Islam online. Jakarta.

Mansur, A., Husaini, A., Mujahidin, E., \& Tafsir, A. (2016). Model pengajaran karakter kejujuran menggunakan teknologi informasi dan komunikasi (studi inovasi pembelajaran di Pondok Pesantren AlAzhaar Lubuklinggau). Ta'dibuna: Jurnal Pendidikan Islam, 5(1), 1-24. https://doi. org/10.32832/tadibuna.v5i1.584

Margianto, J. H., \& Syaefullah, A. (2006). Media online: Pembaca, laba, dan etika: Problematika praktik jurnalisme online di 
Indonesia. Majalah Pusat Dokumentasi ELSAM, 33.

Nurhakim, M. (2011). Imam Zarkasyi dan pembaharuan pesantren: Rekonstruksi aspek kurikulum, menejemen dan etika pendidikan. Progresiva, 5(1), 83-96. Retrieved from https://www.neliti.com/ publications/162206/imam-zarkasyi-danpembaharuan-pesantren-rekonstruksiaspek-kurikulum-menejemen-d

Prasanti, D., \& Indriani, S. S. (2017). Etika komunikasi dalam media sosial bagi ibu-ibu PKK di Desa Mekarmukti Kab. Bandung Barat (studi deskriptif kualitatif tentang etika komunikasi dalam media sosial bagi ibu-ibu PKK di Desa Mekarmukti Kab. Bandung Barat). Profetik: Jurnal Komunikasi, 10(1), 21-34. https://doi. org/10.14421/pjk.v10i1.1219

Putri, N. E., Hakim, N., \& Yamin, M. (2016). Ecological footprint and biocapacity analysis for flooding prevention in South Sumatera. Jurnal Mimbar, 32(1), 58-64. https://doi.org/https://doi.org/10.29313/ mimbar.v32i1.1729

Rosenberg, M. J., \& Foshay, R. (2002). E-learning: Strategies for delivering knowledge in the digital age. Performance Improvement, 5(2). https://doi.org/10.1002/ pfi. 4140410512

Sholihah, K. (2016). Analisis literasi digital: Studi pemanfaatan jurnal elektronik oleh mahasiswa Magister Manajemen di Perpustakaan UKSW Salatiga. UIN Sunan Kalijaga Yogyakarta.

Staff Sekretaris PMDGF. (2017). Serba serbi serba singkat Pondok Modern Darussalam Gontor. Gontor: Pondok Modern.

Supriadi. (2016). Panca jiwa sebagai asas nilai pendidikan pesantren. Al-'Ibrah: Jurnal Studi Keislaman, 12(1), 81-100. Retrieved from http://jurnal.stit-rh.ac.id/index.php/ ibrah/article/view/42

Tamin, I. H. (2011). Peran filantropi dalam pengentasan kemiskinan di dalam komunitas lokal. Jurnal Sosiologi Islam, 1(1), 35-58. Retrieved from http:// jurnalfisip.uinsby.ac.id/index.php/JSI/ article/view/8

Walidah, I. Al. (2018). Tabayyun di era generasi millenial. Jurnal Living Hadis, 2(1), 317-344. https://doi.org/10.14421/ livinghadis.2017.1359

Watie, E. D. S. (2016). Komunikasi dan media sosial (communications and social media). Jurnal The Messenger, 3(1), 69-74. https:// doi.org/10.26623/themessenger.v3i2.270 